\title{
Ruslands magtpolitik i Mellemøsten
}

\section{Ariel Cohen}

\section{Russisk udenrigspolitik har et post-Bismarck anstrøg over sig: Arrogant overdrivelse af egen magt og undervurdering af den amerikanske modstander. Det er tydeligt, at de postkommuni- stiske hvedebrødsdage er ovre, døde og begravede}

Februar 2007 bragte et vendepunkt i de russisk-amerikanske relationer.

To skelsættende begivenheder - den russiske præsident, Vladimir Putins, tale ved Wehrkunde-sikkerhedskonferencen i Tyskland og hans efterfølgende besøg i Saudi-Arabien, Qatar og Jordan - har bebudet, at Rusland er nået frem til en status som 'uafhængig magtpol' i verden efter Den Kolde Krig.

Dette er en gunstig position, som Rusland og dets sikkerhedseliter har $\varnothing n s k e t$ at indtage, lige siden det lykkedes for Jevgenij Primakov at undergrave udenrigsminister Andrej Kozyrev i 1995, da han rykkede fra sit hovedkvarter i Jasenevo, hvor han var chef for udenrigs-efterretningstjenesten, SVR, og over i udenrigsministerens stol i den stalinistiske 'bryllupskage'-skyskraber på Smolenskaja Plosjtjad.

Det kolde styrtebad, som Putin slap løs over USA ved den internationale sikkerhedskonference i München den 1. februar burde ikke være kommet bag på nogen. Trods alt havde Putin selv og en række andre højtstående regeringstalsmænd, deriblandt forsvarsminister Sergej Ivanov (åbenlyst en af Putins 'officielle' arvtager-kandidater) og den militære generalstabschef, Jurij Baluevskij, tidligere udsendt lignende signaler.

Den liste over klagepunkter, som Putin foreholdt USA og Vesten er lang. Hovedanken er, at den amerikanske 'hypermagt' forfølger sin egen unilaterale udenrigs-, forsvars-, kultur- og økonomiske politik, lader 
hånt om international lov og ignorerer FN (hvor Rusland har vetoret $\mathrm{i}$ Sikkerhedsrådet). Frankrigs præsident, Jacques Chirac, ville kunne nikke bifaldende. Dog driver Rusland sin modstand langt videre, end Frankrig nogensinde har gjort.

Putin beskyldte USA for at udvide NATO op til Ruslands grænser og for at indsætte ' 5.000 bajonetter' $i$ hver af de fremskudte baser i Rumænien og Bulgarien. Han fordømte planer for amerikanske missilforsvarsbaser i Centraleuropa, formentlig i Polen og/eller Tjekkiet, og latterliggjorde det påståede mål for sådanne installationer som et forsvar imod missilangreb fra Iran eller Nordkorea. Putin gav klart udtryk for, at missilforsvarets egentlige mål snarere var at neutralisere Ruslands evne til nukleare gengældelsesslag en destabiliserende faktor i den russiske bog om atomvåbenscenarier.

Ydermere anklagede han Washington for ikke at leve op sine traktatlige forpligtelser om kernevåbennedrustning og for at forsøge at skjule i hundredvis af kernevåben i lagerhaller "under tæppet og under dynen".

For yderligere at forstærke sit retoriske overkill, bebrejdede Putin USA's udenrigspolitik for at være skyld i den mislykkede nukleare ikke-spredning ved at implicere om ikke en retfærdiggørelse så dog en forklaring på Nordkoreas og Irans bestræbelser på at anskaffe sig masseødelæggelsesvåben.
Putin rettede en sønderlemmende kritik imod de NATO-medlemmer, som afviser at ratificere CFEtraktaten (om Konventionelle Styrker i Europa), påtalte OSCE's indsats for fremme af demokrati, advarede imod at tilstå Kosovo uafhængighed og tog afstand fra vestlig kritik af menneskerettighedernes tilstand i Rusland.

Hvor var Putins retningslinjer for internationale relationer? Han udbredte sig i nostalgiske vendinger om den bipolare verden, dengang da USA og Sovjetunionen regulerede hinandens ambitioner igennem den nukleare terrorbalance, der kendtes som MAD-doktrinen (Mutual Assured Destruction - gensidigt garanteret tilintetgørelse). Mange russiske og vestlige eksperter opfatter Putins tale som en yderligere afstandtagen fra det europæisk-atlantiske fællesskab, hvis ikke ligefrem en ny koldkrigserklæring.

\section{Tilbage til fremtiden?}

Putins München-tale og rejse til Saudi-Arabien, Qatar og Jordan den følgende uge signalerede med brask og bram over for Washington, at Rusland har brudt med Vesten, hvilket flere klartskuende analytikere da også havde advaret om ville ske i måneder forinden. Moskva forfølger en politik, der åbenlyst har til målsætning at holde Washingtons magt $i$ ave.

Moskva bruger hele skalaen af redskaber i moderne internationale 
relationer til at nå sine mål: Fra offentligt diplomati til våbensalg; fra strategiske informationsoperationer (SIO'er), der tilsigter at skildre Amerika som en hypermagt ude af kontrol, der truer det internationale samfund, til kurtisering af terroristorganisationer. Således har Khaled Mashal, Hamas' øverste terroristleder, besøgt Moskva for anden gang på et år, og Putin har gentagne gange fremført, at Moskva ikke opfatter Hamas og Hizbollah som terroristorganer, uanset at adskillige USA- og EU-resolutioner har den stik modsatte vurdering.

Reelt har Moskva foretaget et brud med 'enhedsfronten' mod international terror og stiler nu imod at indgå en særaftale - en hudna (våbenhvile, red.) - med islamisterne.

\section{Putins Fulton}

München-talen har en række indenrigspolitiske og internationale 'drivmidler', som føjer yderligere til billedet af et Rusland, der kræver strategisk paritet med USA og definerer sin nationale identitet i et modsætningsforhold til Vesten.

Mens russerne med stor entusiasme favnede et privatiseret erhvervsliv, designer-mærkevarer og ferierejser til Costa del Sol, var de mere sendrægtige til at internalisere pluralistiske værdier, støtte ytrings- og pressefrihed og forsvare menneskerettigheder. Retsstatsprincipper i
Rusland befinder sig langt fra vestlige normer.

Adskillige års stadig mere skinger antiamerikansk og antivestlig propaganda i regeringstro og nationalistiske medier har fremavlet en generation af russere, som er etnocentriske og forkaster liberale værdier. I en nylig meningsmåling støttede 60 pct. af de adspurgte slagordet 'Rusland for russere'.

Vedvarende nationalistisk og antiamerikansk hjernevask har slået bro over kløften mellem sovjetisk supermagtschauvinisme og den nye russiske selvbevidsthed, som den næres af massive olieindtægter og nationalisme.

Den 'Amerika-som-fjenden'-konstruktion, der promoveres af Kremlfinansierede spinmestre, som i Rusland kendes som 'politiske teknologer', forstærker det nuværende regimes legitimitet - et regime, som i vidt omfang ledes af tidligere KGBofficerer - som Moder Ruslands forsvarer. Det afviser kategorisk at integrere Rusland i det globale økonomiske og politiske fællesskab, som den anden officielle 'arvtagerkandidat', vicepremierminister Dimitrij Medvedev, antydede i sin tale ved Davos World Economic Forum i januar 2007.

På den anden side viser Putins besøg i Indien, som var tilrettelagt af forsvarsminister Ivanov, hvor Putin underskrev en aftale om fælles udvikling af et stealth-kampfly, og hans rundrejse i Mellemøsten (mere her- 
om i det følgende), at Rusland søger at spille en rolle som en alternativ supermagt på den østlige halvkugle.

Rusland henvender sig navnlig til den muslimske verden, som er optændt af antiamerikansk og antivestlig modvilje. Rusland leverer våben og ledelse i globale sammenhænge og organisationer såsom FN. Denne kurs bliver styrket af Ruslands observatørstatus i Den Arabiske Liga og Den Islamiske Konferenceorganisation. Trods fraværet af sovjetideologiens globale rækkevidde, formår Rusland med denne politik alligevel at indskrænke Washingtons handlingsspillerum.

I en epoke med rekordstore amerikanske militærbudgetter ønsker Rusland ikke at sakke agterud. Det har planer om at bruge 189 mia. dollar over de næste fem år på en fremskyndet militær modernisering. 8. februar fremlagde forsvarsminister Ivanov det nye rustningsprogram, der omfatter nye atomunderundervandsbåde og hangarskibe, en flåde af nye TU160-overlydsbombefly og udviklingen af et femte generations-kampfly.

Rusland starter også produktionen af en svært bevæbnet helikopter, der kendes under betegnelsen Black Shark. Med sit konventionelle og nukleare fokus har dette program tydeligvis snarere til formål at modbalancere USA's magt end at bekæmpe terrorister i Kaukasus. Det behøver USA som glaunij protiunikhovedmodstander.
Rusland forsøger også at få del i våbenmarkedet især for skurke- og semiskurkestater. Rusland er største våbenleverandør til Kina og Iran. Det har underskrevet en våbenhandel med Hugo Chávez' Venezuela til tre mia. dollar på trods af amerikanske indvendinger og kurtiserer flere potentielle mellemøstlige kunder.

Rusland er kun alt for glad for at spille på den arabiske og muslimske gades antiamerikanske følelser og signalere, at USA, som står over for alvorlige vanskeligheder i Irak, ikke kan udøve eksklusiv strategisk dominans i Den Persiske Golf og Mellem$\emptyset$ sten. Moskva er for alvor tilbage i verdens vigtigste energidepot. Således er det ikke noget tilfælde, at $\mathrm{Pu}$ tin holdt sin München-tale, umiddelbart før han skulle besøge SaudiArabien som den første russiske eller sovjetiske leder nogensinde, foruden Qatar og Jordan, Amerikas traditionelle forbundsfæller i Mellemøsten.

\section{Kurmageri til amerikanske klienter}

Putins besøg i Mellemøsten var udsøgt timet til at falde sammen med Amerikas værste krisestund i regionen med indsættelsen af de kontroversielle troppeforstærkninger i Irak og Afghanistan. Putin besøgte også de amerikanske allierede Jordan og Qatar. Efter München skitserede Putin i et interview med al-Jazeera ydermere en ny russisk mellemøstpolitik, der går på tværs af Washington. 
Putin gentog Ruslands modstand imod Irak-krigen og anfægtede, at Saddams henrettelse var gået retfærdigt til. Han var også kritisk over for USA's demokratikampagne i Mellemøsten og henviste til, at styrkelsen af Hamas og Hizbollah blev resultaterne af de parlamentsvalg i de palæstinensiske områder og Libanon, som Washington havde presset på for. Samtidig, med en noget haltende logik, retfærdiggjorde han Ruslands afvisning af at anerkende Hamas og Hizbollah som terroristorganisationer ved at påberåbe sig deres sejre i demokratiske valg.

Dog fremhævede han ikke de dybereliggende grunde til at favne Hamas og Hizbollah - nemlig de stadig tættere bånd til det Iran, som sponserer de to radikale organisationer; forsøget på at knytte bånd til større islamiske stater og bevægelser, som støtter Hamas; og bestræbelserne på at hindre islamistisk støtte i at nå frem til Ruslands stadig mere fanatiserede islamistiske folkegrupper i det nordlige Kaukasus og hinsides denne region.

Under sit besøg i den saudiarabiske hovedstad forbløffede Putin verden yderligere ved at tilbyde at sælge Saudi-Arabien 'fredelige' atomreaktorer. Ydermere tilbød han $150 \mathrm{~T}$ 190-kampvogne og andre våben. Under sin Mellemøstrundtur tilkendegav den russiske præsident Ruslands beredvillighed til at sælge helikoptere, bygge fabrikker til fremstilling af raketfremdrevne granater, le- vere sofistikerede antiluftskyts-systemer - og satte så trumf på ved at tilbyde saudierne udvidede satellitopsendelser og en mulighed for at deltage i det russiske satellitnavigationssystem, GLONASS.

Under sit besøg i Qatar, verdens tredjestørste leverandør af naturgas, bemærkede Putin endvidere, at det iranske forslag om at danne et OPEC-lignende kartel for gasproducenter var 'en interessant idé' - efter at hans minister først havde afvist det blankt - og inviterede saudiske banker til at åbne helt selvejede underfilialer i Rusland.

Putin opsummerede Ruslands nye udenrigs- og mellemøstpolitik, som følger:

"Af hensyn til stabiliteten i den ene og den anden region eller i verden generelt er magtbalancen den vigtigste bedrift gennem de seneste årtier, ja i hele menneskehedens historie er den en af de vigtigste forudsætninger for at opretholde global stabilitet og sikkerhed...

Jeg forstår ikke, hvorfor nogle af vore partnere [Europa og USA AC] ... opfatter sig selv som klogere og mere civiliserede og forestiller sig, at de har ret til at påtvinge andre deres normer. Det afgørende at huske på her er, at normer der påtvinges udefra, herunder også $\mathrm{i}$ Mellemøsten, frem for at være produkt af et samfunds naturlige, indre udvikling, vil føre til tragiske konsekvenser, og det bedste eksempel på dette er Irak." 
Denne Realpolitik-tale blev lovprist i arabiske hovedstæder, hvor den gamle sovjetiske antivestlige og antiisraelske holdning stadig mindes med glæde. Saudi-Arabiens kong Abdullah I tildelte Putin Kong Faisal-prisen og kaldte ham "en statsmand, en fredens mand og en retfærdighedens mand" - noget af en kovending, siden dengang saudierne for tyve år siden finansierede hellige krig imod den sovjetiske besættelsesmagt i Afghanistan.

Det er også værd at notere sig, at Saudi-Arabien officielt fordømmer de 100.000 dræbte og 500.000 fordrevne muslimer i Tjetjenien, og at Golfen er hjemsted for private grupper, der støtter terroristerne i Kaukasus. Alligevel blev Tjetjenien ikke bragt på bane under besøget, samtidig med at den Moskva-loyale sekulære leder af Tatarstan, Minitimer Shajmijev, som ledsagede Putin, af Abdullah ligeledes fik en Kong Faisal-pris for at have tjent islams sag.

\section{Afghanistan}

Ruslands politisk-militære elite betragter det sovjetiske nederlag i Afghanistan (1979-89) som en væsentlig medvirkende faktor til Sovjetunionens sammenbrud. Ydermere deles denne vurdering af ledere af den globale islamistiske bevægelse, herunder Osama bin Laden selv.

I 1990'erne var Rusland særdeles bekymret over Taleban. I 1999 foreslog Andrej Kokosjin, minister for
Ruslands nationale sikkerhed, at bombe Taleban i tilfælde af at det truede Centralasien. Ledende russiske analytikere har været inde på noget lignende. I februar 2002 medgav den russiske generaloberst Leonid Ivasjov over for avisen Nezavisimaja Gazeta, at "vi kun kan spille en sekundær rolle i det land. [Rusland] har ikke noget brohoved i Afghanistan i dag".

Siden da har Rusland søgt at genvinde indflydelse i Afghanistan og sikre sig selv og omegnen imod Afghanistans to dødbringende eksportartikler - terrorister og narkotika.

I september 2005 udtalte Mikhail Kamynin, talsmand for det russiske udenrigsministerium: "At hjælpe Afghanistan med at løse en lang række problemer er uden tvivl et de højest prioriterede mål for russisk udenrigspolitik og en vigtig del af vores bestræbelser for at bekæmpe international terrorisme, illegal produktion og smugling af narkotika og for at styrke regional sikkerhed og stabilitet".

I det russiske udenrigsministeriums statusrapport fra marts 2007, tales der således om behovet for at 'afmonopolisere' den politiske kontrol over Afghanistan. Implicit er en sådan position rettet imod USA's og NATOs politik i landet. Statusrapporten udtrykker også frygt for, at ustabilitet vil blive konsekvensen, når USA- og NATO-koalitionsstyrkerne forlader Centralasien, hvilket ikke vil efterlade Rusland andet valg 
end at opbygge sin egen direkte og multilaterale involvering i regionen.

Den afghanske narkotikaproduktion repræsenterer en betydelig trussel for den russiske befolkning. Over 30 pct. af de afghanske familier er involveret i en eller anden form for dyrkning og fremstilling af opium, hvad der indbragte en bruttoind tægt på omkring 1,2 mia. dollar i 2002. I dag tegner denne industri, der omsætter for 2,6 mia. dollar, sig for over en tredjedel af Afghanistans økonomi. Mellem 80 og 90 pct. af heroinen kommer til Rusland fra Afghanistan. Det skønnes, at omkring 70.000 russere hvert år dør af afghanske stoffer.

Antinarko-bestræbelser udgør en væsentlig del af Ruslands udenrigspolitik over for Afghanistan. Den russisk ledede Kollektive Sikkerhedstraktatorganisation (CSTO) nedsatte en arbejdsgruppe om Afghanistan 23. juni 2005, primært for at anbefale metoder til at bekæmpe narkotruslen. Efter sit møde i Kabul fra 9. til 13. marts 2007 udtalte arbejdsgruppen sin hensigt om at gøre sit antinarko-initiativ, Channel 2006 - et midlertidigt Afghanistan-projekt til et permanent regionalt program.

I førnævnte statusrapport fra marts 2007 indvilger det russiske udenrigsministerium $i$ at arbejde under Rusland-NATO-rådets auspicier om et pilotprojekt, der med de russiske antinarko-divisioner som grundlag skal træne afghanske og centralasiatiske sikkerhedsstyrker.
Før 11. september havde Rusland bistået Nordalliancen i dens kamp mod Taleban med våbenhjælp til millioner af dollar. Efter at Amerika rykkede ind i regionen i kølvandet på $11 / 9$, har de russiske bestræbelser på at genvinde indflydelse strakt sig over næsten enhver form for militærbistand med undtagelse af at sende tropper til Afghanistan.

Så tidligt som 2002 forhandlede Afghanistans interim-forsvarsminister, Mohammad Fahim, med den tidligere forsvarsminister og nuværende vicepremierminister Sergej Ivanov om at levere Afghanistan kampvogne, panserkøretøjer, kampfly og andet udstyr, herunder transportfly, helikoptere og kommunikationsudstyr.

Siden da, fra 2002 til 2003, har Rusland leveret hovedsageligt forældet militærudstyr til en værdi af 200 mio. dollar til Afghanistan.

Under deres topmøde i marts 2007 i Kabul tilbød CSTO's Afghanistan-arbejdsgruppe at yde bistand til at opbygge den afghanske hær og sikkerhedstjenester og forstærke grænsebeskyttelsen. Ved et tidligere møde i 2002 gav den russiske minister for nødsituationer, Sergej Shoigu, tilsagn om at oprette et minerydningscenter i Kabul.

\section{Økonomisk bistand}

Ruslands økonomiske bistand har været en afgørende støttepille for dets politik over for Afghanistan. I 
henhold til Bonn-aftalen fra december 2001, som etablerede den afghanske provisorieregering, har Rusland hjulpet Afghanistan med 30 mio. dollar i bistandsmidler og over 200 mio. til udvikling af sikkerhedsinfrastrukturer. Faktisk spillede Rusland en afgørende medvirkende rolle i udformningen af Bonn-aftalen, da den russiske ambassadør gjorde den afghanske udenrigsminister, Abdullah Abdullah, klart, at Afghanistan ikke kunne forvente yderligere russisk bistand, hvis ikke de forskellige fraktioner i landet ville slutte op om aftalen. Trods bekymringer for USA's tilstedeværelse gav Rusland i februar 2007 tilsagn om en støttepakke, som skal hjælpe NATO med at knuse Talebans oprør.

Rusland har også drøftet at annullere den 'gæld' (besættelsesomkostningerne), som Afghanistan oparbejdede under Sovjet-Afghanistankrigen 1979-1989. I januar 2007 erklærede den russiske vicefinansminister, Sergej Stortjak, at Rusland er parat til at annullere gæld for 10 mio. dollar, under forudsætning af at Afghanistan vil anerkende denne gæld.

I februar 2007 sagde Ruslands udenrigsminister, Sergej Lavrov, at Rusland og Afghanistan er blevet enige om at regulere gælden efter de ordninger, der er fastsat af Parisklubben, en uofficiel sammenslutning af verdens 19 rigeste kreditorer. Til gengæld vil russiske selskaber 'få nye muligheder på det af- ghanske marked', navnlig inden for olie, gas, minedrift og elektricitetssektoren.

Samme måned sluttede USA sig til Rusland og Tyskland, de tre medlemmer af Paris-klubben, som Afghanistan har gældsforpligtelser overfor, og annullerede hele sit tilgodehavende på 108 mio. dollar.

Rusland har anvendt bilaterale og multilaterale fremgangsmåder for at genoprette sine afghanske forbindelser. I 2002 genfremsatte Ruslands udenrigsminister, Igor Ivanov, et forslag om en fælles NATO-CSTO-aktion i Afghanistan. Ivanov gik så vidt som til at betegne Moskva som 'Afghanistans gamle ven'.

I februar 2007, sagde CSTO's generalsekretær, Nikolai Bordjusja, at CSTO's medlemsstater har til hensigt at yde bistand til Afghanistan til dannelsen af dets nationale hær og andre magtstrukturer. Ved en pressekonference samme måned sagde udenrigsminister Lavrov, at Rusland var rede til at investere $i$ afghansk brændstof, gas, elektricitet og cementforsyninger; optage flere afghanske studerende på russiske universiteter; genopbygge Kabuls Polytekniske Universitet og udruste den afghanske hær. Fire dage senere fløj Lavrov til Kabul for at genåbne den russiske ambassade.

Der er således to geo- og sikkerhedspolitiske hensyn, der styrer Ruslands politik over for Afghanistan. For det første ønsker Rusland at begrænse den amerikanske tilstedevæ- 
relse og forhindre, at USA vinder permanent fodfæste i dette land. For det andet ønsker Rusland at tøjle og begrænse Talebans og al-Qaedas indflydelse. Hvor det første hensyn i nogen grad er en nationalistisk mani, er den anden trussel i stand til at destabilisere Ruslands allierede i Centralasien, og risikoen er i fremtiden, at den vil kunne udstrække sin indflydelse til selve Den Russiske Føderations eget territorium.

\section{Iran}

Russisk (og før det sovjetisk) udenrigspolitik over for Iran har fokuseret på at opbygge den islamiske republik som en regional modvægt til USA og dets sunniarabiske allierede i Den Persiske Golf, herunder at styrke Teherans konventionelle våbenprogrammer, give det nukleare kapaciteter såvel som at træne dets sikkerhedstjenester - alt sammen for at hjælpe Iran til at virkeliggøre dets længe nærede higen efter regionalt overherredømme.

I dag fortsætter Rusland med at levere Iran konventionelle våben. Rusland solgte våben til begge sider under Iran-Irak-krigen. I 1990'erne solgte Moskva ballistisk missilteknologi til Iran og engagerede sig i overførelse af atomteknologi og uddannelse af forskere og ingeniører. Rusland solgte Iran 29 TOR-M1-missiler for 700 mio. dollar i henhold til en kontrakt, der blev underskrevet $\mathrm{i}$ 2005. TOR-M1 er et højpræcisions- missilsystem designet for at ødelægge fly og krydsermissiler, der flyver i højder op til 9,5 km. Som det seneste eksempel, testede Iran den 7. februar med succes TOR-M1-antiluftskystmissilsystemet, som det havde indkøbt fra Rusland samme måned.

For det andet bruger Rusland Iran til at udvide sit olie- og gasmonopol i regionen. I maj 2007 tilkendegav Abubakir Shamusov, chef for Gazproms afdeling i Iran, at Gazprom var interesseret i den planlagte Iran-Pakistan-Indien-gasrørledning. Rørledningen vil strække sig $2.700 \mathrm{~km}$ fra Iran til Indien over Pakistan og vil dagligt levere 90 mio. kubikmeter gas til Indien og 60 mio. kubikmeter til Pakistan.

USA har modsat sig denne rørledning og foretrækker i stedet en forbindelse, der fører fra Turkmenistan til Indien over Afghanistan og Pakistan. Men Indien har, sammen med Rusland og Iran, tilkendegivet, at de amerikanske bekymringer ikke vil influere på deres handlinger.

Endelig, som det mest afgørende, har Rusland spillet en rolle som fødselshjælper for Irans optagelse i den eksklusive atomklub. Det russiske atomkraftselskab Atomstroiexport har opført et atomkratværk til 1 mia. dollar i den iranske havneby Bushehr og dermed opfyldt en kontrakt, der blev underskrevet i 1995. I februar 2005 sagde Rusland ja til at levere uran til Bushehr-reaktoren.

Da de internationale spændinger om Irans uranberigelsesprogram 
nåede et foreløbigt kulminationspunkt i marts 2007 gik Rusland dog med at forhale uranleverancen under indtryk af de amerikanske og vestlige indvendinger og med henvisning til påståede iranske forhindringer $i$ afbetalingen af reaktoren.

Irans antivestlige adfærd har ført de fleste iagttagere til den antagelse, at dets nukleare bestræbelser vil kulminere i konstruktionen af et atomvåben. Men da den amerikanske udenrigsminister, Condoleezza Rice, udtalte, at Iran end ikke har behov for et civilt atomprogram, svarede Ruslands udenrigsminister, Sergej Lavrov, tilbage, at Iran er sin gode ret til at råde over hele den nukleare brændstofscyklus.

Ifølge Det Internationale Atomenergiagentur (IAEA) kan Iran i juni 2007 have tilstrækkeligt med operationsklare centrifuger til at berige uran til våbenpotentiale, $\operatorname{der} \mathrm{i}$ nukleart materiale svarer til en bombes værdi om året.

Rusland har markeret, at det i princippet er imod, at Iran anskaffer sig atomvåben. I sin kontrakt vedrørende uranleverancer har Rusland krævet, at Iran slutter sig til IAEA-Protokollen om Supplerende Garantier fra 1993, ifølge hvilken IAEA skal have mulighed for at gennemføre omfattende overraskelsesinspektioner.

Når Amerika i nær fremtid kommer til at stå over for en genopvakt iransk stormagt med mulige atomvåben, som gør krav på regionalt he- gemoni, må det sande, at Rusland, tilsammen med Kina og Nordkorea, var den primære katalysator for denne udvikling.

\section{På kollisionskurs med Vesten}

En række faktorer er styrende for Putins seneste retorik og aktioner i Mellemøsten. Ved at favne de mellemøstlige monarkier og den autoritære islamisme i Iran manifesterer han for det første Ruslands fortsatte afstandtagen fra vestlige normer for politisk adfærd. Dette har betydningsfulde implikationer, idet 20072008 er valgår i Rusland. Putin forkaster nu højlydt den amerikanske demokrati- og menneskerettighedstilgang, som er vaklet og snublet i Mellemøsten.

For det andet følger Rusland den sovjetiske model for at modsætte sig først britisk og derpå amerikansk tilstedeværelse ved at spille på de antivestlige følelser i 'gaden' og blandt eliterne. Putins München-tale, hans al-Jazeera-interview og hans pressekonferencer i Jordan og Qatar forstærkede det budskab, der var udgået fra Kremls offentlige diplomati ved at understrege modsætningsforholdet til Washington.

For det tredje er den russiske ledelse bekymret over de høje muslimske fødselsrater i Rusland, især fordi den slavisk-ortodokse befolkning i er i tilbagegang. Rusland står over for en stadig mere radikaliseret muslimsk befolkning ved sin 'bløde 
sydflanke', navnlig i Nordkaukasus, hvor de to krige i Tjetjenien (1994 og 1999), skønt russernes sejre var knusende, har ført til en øget udbredelse af salafistisk islam. Mange unge russiske muslimer ser i højere grad sig selv som medlemmer af den globale islamiske Ummah (fællesskab) end som borgere i Moder Rusland. At holde muslimske magter såsom Saudi-Arabien og Iran i skak, at afholde dem fra at støtte oprørsbevægelser i Eurasien og nedtone radikalisering igennem islamistisk uddannelse og propaganda er en vigtig politisk målsætning på Kremls agenda.

Endelig er Rusland en højomkostnings-olieproducent, som i uforholdsmæssig stor grad drager fordel af de aktuelle høje oliepriser. Rusland er den største olie- og gasproducent i verden og den største olieeksportør uden for OPEC. Som sådan er det interesseret $i$ at fastholde det høje energipris-miljø, som, inter alia, er et resultat af Mellemøstens konflikter og spændinger.

Rusland er fuldkommen beredvillig til at sælge våben til begge side af den voksende sunni-shia-kløft. Dette blev tydeligt, da de samme atomreaktorer - fredelige, selvfølgelig og de samme antiluftskytssystemer blev tilbudt til både Iran og de arabiske golfstater, som er stedse mere nervøse over Irans voksende militærmagt og nukleare ambitioner. Som en russisk iagttager formulerer det, skaber våbensalg allierede.
Rusland bruger våben og atomreaktorsalg i dag på samme måde, som det kejserlige Tyskland brugte jernbaner før Første Verdenskrig til at tiltrække allierede, styrke indflydelse og undergrave Mellemøstens dominerende magt.

\section{Hvordan kommer vi videre?}

Set fra Washingtons perspektiv kunne timingen for Putins tale dårligt være værre. Med et Irak i skærsilden og et stridbart Iran var chancerne for at opnå russernes samarbejde til at tæmme Teherans nukleare ambitioner i forvejen spinkle. Rusland var vrangvillig over for at lægge det nødvendige pres på Iran under forhandlingerne i december 2006 om FN's sikkerhedsrådsresolution 1737 og kan meget vel afvise dette igen, når sikkerhedsrådet igen skal behandle det iranske dossier inden for få uger.

Ydermere signalerer Putin, at Rusland er rede til at påtage sig en ledende rolle for den antiamerikanske lejr i Europa og Mellemøsten, og fra Caracas til Beijing sætter Rusland ikke blot militær magt bag sin retorik, men også økonomiske muskler: Putin har offentligt overvejet den iranske øverste leder, ayatollah Ali Khameneis, idé om at skabe et internationalt kartel for naturgas efter OPEC-forbillede.

Et sådant kartel er langt fra let at oprette, eftersom langt hovedparten af naturgassen overføres i rørlednin- 
ger og ikke handles på spotmarkeder som flydende naturgas (LNG). Gaspriser er fastlagt efter langsigtede kontrakter og kan ikke sættes ved at manipulere med forsyningerne. Hvorvidt en gasblok bliver til noget, og om den vil blive omsat til en militær alliance, står tilbage at se.

\section{En neorealistisk tilgang}

Billedet af en ny Kold Krig kan meget vel være en overforenklet fremstilling af det fremvoksende forhold til Rusland. Sandt at sige har russisk udenrigspolitik et udpræget postBismarck anstrøg over sig: Muskuløs, arrogant, overdrivelse af egen magt og undervurdering af den amerikanske modstander, han er så forhippet på at genskabe.

Denne politik har stor risiko for at blive til en selvopfyldende profeti med farlige konsekvenser og høje omkostninger, såvel finansielt som i sidste ende i blod. Det er tydeligt, at de postkommunistiske hvedebrødsdage er ovre, døde og begravede. En realistisk vurdering af forholdet er på sin plads.

USA bør huske på, at det har strakt sine ressourcer til det yderste og ikke behøver nogen ny kold krig med en betydelig landmagt. USA er fuldt engageret $i$ to regionale konflikter - i Irak og i Afghanistan - og i den globale krig mod terror.

Bag fjernere horisonter kan forholdet til Kina en dag gå hen og blive kompliceret.
Tiden er derfor ikke til nogen retorisk konfrontation med Moskva. Hertil kommer, at det er værd at indprente sig, at Moskva sætter pris på vished i relationer og respekterer magt og handling. Gerninger og ikke ord er nødvendige for at sende det budskab til Kreml, at USA og dets allierede ikke vil lade sig kujonere, men at Washington ej heller er interesseret i et fornyet fjendskab.

Det står klart, at det nye Mellemøsten, hvor amerikansk magt og prestige er truet i Irak, og hvor Moskva udfordrer USA's supermagtstatus vil blive et vanskeligt miljø at manøvrere i og blive præget af betydelig rivalisering. Vore dages Mellemøsten bør betragtes med den realisme og barskhed, som dets historie og kultur kræver.

Som en status quo-magt i Mellemøsten bør USA styrke sine relationer med Golfens provestlige regimer. Skønt nogle våbensalg og forretningsprojekter med Rusland uundgåeligt vil finde sted, kan USA kun opretholde en sikkerhedsparaply i Golfen ved at sikre sig større indflydelse i regionen end Rusland.

Washington bør udstede de militære forsikringer til Golf-nationerne imod iransk indtrængen, som Rusland er ude af stand til at give; udvide samarbejdet i kampen mod den terrorisme, som truer de mellemøstlige monarkier; sikre sin konkurrencedygtighed inden for de afgørende økonomiske satsningsområder, hvor Rusland mangler ekspertise, og sam- 
tidig give mellemøstlige forretningsudviklingsprojekter fra venligtsindede lande adgang til de amerikanske kapitalmarkeder.

Tiden er også inde til at bygge bro til potentielle russiske allierede for at hindre antiamerikanske blokke i at opstå. USA bør også appellere til sine traditionelle allierede i Europa og andre steder om at anerkende den ændrede geostrategiske balance på den østlige halvkugle, at forstærke det gensidige forsvar, at koordinere energipolitikken og samarbejde om energisikkerhed blandt energikonsumenterne.

Samtidig bør USA forsætte dialogen og samarbejdet med Rusland om anliggender, der ligger dem gensidigt på sinde såsom energi, især atomenergi, og ikke-spredning af masseødelæggelsesvåben og rumforskning. Washington bør fortsætte diskussionerne om emner af gensidig interesse såsom nuklear ikkespredning, terrorisme og destabiliserende våbensalg.

Efter 20 års dvale, er Rusland igen ved at tiltvinge sig adgang gennem Mellemøstens åbne dør. Washingtons beslutningstagere vil gøre klogt $\mathrm{i}$ at indprente sig dette.

Ariel Cohen, Ph. D., er seniorforsker $i$ russiske og eurasiske studier og international energisikkerhed ved Sarah og Douglas Allison Center of the Davis Institute for International Studies under Heritage Foundation. Han er forfatter til 'Russian Imperialism and Crisis' (1998), 'Eurasia in Balance' (2005) og 'Kazakhstan: Energy Cooperation with Russia Oil, Gas and Beyond' (2006)

Oversat af Niels Ivar Larsen 